Otentik's: Jurnal Hukum Kenotariatan (Vol 2, No. 2, Juli 2020)

p-ISSN 2655-5131 e-ISSN 2685-3612

\title{
Peran Mejelis Pengawas Notaris Dalam Menjalankan Kewenangannya Terhadap Laporan Masyarakat
}

\author{
Ahmad Zacky \\ Ahmadzacky1996@gmail.com
}

\begin{abstract}
Abstrak
Dalam hal adanya laporan masyarakat terhadap dugaan pelanggaran yang dilakukan oleh notaris maka akan diperiksa oleh MPD, hasil pemeriksaan MPD selanjutnya merekomendasikan terhadap adanya dugaan pelanggaran Kode Etik maupun UUJN kepada MPW, MPW akan menyelenggarakan sidang dengan memanggil pihak pelapor dan pihak terlapor akan tetapi sering kali pihak pelapor dan pihak terlapor tidak menghadiri persidangan, walaupun telah dilakukan upaya pemanggilan dari MPN. Hal ini menjadi kendala-kendala bagi MPN dalam melaksanakan kewenangannya untuk memeriksa dan memutus terhadap dugaan pelanggaran tugas dan kewenangan notaris.. Berdasarkan uraian tersebut bagaimana peran MPN Provinsi Jawa Barat dalam menjalankan kewenangan terhadap laporan masyarakat dan apa kendala-kendala yang dihadapi. Pengawasan dapat di definisikan sebagai proses untuk menjamin bahwa tujuan-tujuan organisasi dan manajemen dapat tercapai. Metode Penelitian ini adalah yuridis normatif yaitu pendekatan yang menggunakan konsepsi legis positivis. Penelitian ini menggunakan pendekatan perundangundangan dan pendekatan kasus. Penelitian hukum normatif berdasarkan data sekunder lalu di analisis menggunakan analisis deskriptif. notaris mendapat wewenang secara atribusi, karena wewenang tersebut diberikan oleh UUJN. Peran MPN Jawa Barat terhadap laporan masyarakat belum efektif karena pada sidang pemeriksaan tingkat pertama di MPD hanya sebatas menyelenggarakan sidang untuk memeriksa adanya dugaan pelanggaran kode etik notaris atau pelanggaran pelaksanaan jabatan notaris pemeriksaan terhadap dugaan dari laporan masyarakat karena pada dasarnya MPD lebih mengatahui situasi dan kondisi permasalahan yang ada di daerahnya dan ketika hasil pemeriksaan dari MPD direkomendasikan ke MPW baik pelapor maupun terlapor sering tidak hadir dalam proses persidangan yang dilaksanakan MPW. Dan kendala-kendala MPN yaitu tugas pengawasan
\end{abstract}


Otentik's: Jurnal Hukum Kenotariatan (Vol 2, No. 2, Juli 2020)

p-ISSN 2655-5131 e-ISSN 2685-3612

yang dilakukan oleh setiap anggota majelis bukan merupakan pekerjaan pokok, sehingga terkadang sulit bagi setiap anggota majelis untuk mensinergikan waktu antara anggota majelis yang satu dengan yang lain karena anggota majelis memiliki pekerjaan utama masing-masing.

Kata Kunci: Peran, Majelis Pengawas Notaris, Laporan Masyarakat

\begin{abstract}
In the case of a public report of alleged violations committed by a notary will be examined by the MPD, the results of the MPD examination will further recommend that there are alleged violations of the Code of Ethics and UUJN to MPW, MPW will hold a hearing by calling the reporting party and the reported party but often the parties the complainant and the reported party did not attend the hearing, despite efforts to summon the MPN. This becomes obstacles for MPN in carrying out its authority to examine and decide on alleged violations of duties and notary authority. Based on the description of how the role of MPN West Java Province in exercising authority over public reports and what obstacles are faced. Supervision can be defined as a process to ensure that organizational and management objectives can be achieved. This research method is a normative juridical approach that uses a positivist legis conception. This study uses a statutory approach and a case approach. Normative legal research based on secondary data and then analyzed using descriptive analysis. the notary gets the authority in attribution, because the authority is given by UUJN. The role of the West Java MPN on community reports has not been effective because at the first level of hearing at MPD it was limited to holding hearings to examine suspected violations of the notary code of ethics or violations of the implementation of the notary public examination on allegations of public reports because MPD basically knew more about the situation and condition of the problem in the area and when the examination results from the MPD are recommended to the MPW both the complainant and the reported are often not present in the trial process carried out by the MPW. And MPN constraints namely the supervisory task performed by each member of the assembly is not the main work, so sometimes it is difficult for each member of the assembly to synergize the time between one assembly member and another because the members of the assembly have their respective main work.
\end{abstract}

Keywords: Role, Notary Supervisory Board, Community Report

\title{
PENDAHULUAN
}

Notaris dalam menjalankan tugas jabatannya secara institusional diawasi oleh 3 (tiga) institusi, yaitu berdasarkan Undang-Undang Nomor 2 Tahun 2014 tentang Perubahan Undang-Undang Nomor 30 Tahun 2004 tentang Jabatan Notaris melalui Majelis Pengawas Notaris (MPN), Majelis Kehormatan Notaris (MKN) dan Dewan Kehormatan Notaris (DKN) Ikatan Notaris Indonesia. Ketiga institusi tersebut mempunyai kewenangan yang berbeda-beda sebagaimana tercantum dalam aturan hukum yang mengaturnya. 
Otentik's: Jurnal Hukum Kenotariatan (Vol 2, No. 2, Juli 2020)

p-ISSN 2655-5131 e-ISSN 2685-3612

Pasal 67 ayat (2) Undang-Undang Nomor 2 Tahun 2014 tentang Perubahan Atas Undang-Undang Nomor 30 Tahun 2004 tentang Jabatan Notaris ditegaskan bahwa yang melakukan pengawasan terhadap notaris dilakukan oleh Menteri, tanggung jawab menteri dalam melakukan pengawasan tersebut karena notaris diangkat oleh menteri.

Tujuan lain dari pengawasan terhadap notaris, bahwa notaris dihadirkan untuk melayani kepentingan masyarakat yang membutuhkan alat bukti berupa akta otentik sesuai permintaan masyarakat itu sendiri kepada notaris, sehingga tanpa adanya masyarakat yang membutuhkan notaris, maka notaris tidak ada gunanya.

Meskipun demikian, tidak berarti dengan bergantinya instansi yang melakukan pengawasan notaris tidak akan terjadi pelanggaran-pelanggaran yang dilakukan notaris, karena betapapun ketatnya pengawasan yang dilakukan MPN, tidak mudah untuk melakukan pengawasan tersebut, hal ini terpulang kepada notaris sendiri dengan kesadaran dan penuh tanggungjawab dalam menjalankan tugas jabatannya mengikuti atau berdasarkan aturan hukum yang berlaku kepada majelis pengawas notaris setempat, dengan adanya laporan seperti ini dapat mengeliminasi tindakan notaris yang tidak sesuai dengan aturan hukum pelaksanaan tugas jabatan notaris. ${ }^{1}$

Dalam melaksanakan pengawasan tersebut, Menteri membentuk Majelis Pengawas Notaris (MPN), MPN sebagai satu-satunya instansi yang berwenang melakukan pengawasan, pemeriksaan dan menjatuhkan sanksi terhadap notaris, tiap jenjang MPN terdiri dari Majelis Pengawas (MPD, MPW dan MPP) mempunyai wewenang masing-masing.

Sebelum diterbitkannya putusan Mahkamah Konstitusi (MK) Nomor 49/PUU-X/2012 tertanggal 28 Mei 2013, pemanggilan notaris oleh polisi (penyidik) harus mendapat izin dari Majelis Pengawas Daerah (MPD), berdasarkan Pasal 66 Undang-Undang Nomor 30 Tahun 2004 tentang Jabatan Notaris.

Setelah diterbitkannya putusan MK tersebut maka aparat bisa memanggil dan memeriksa notaris tanpa perlu lagi menunggu persetujuan MPD Notaris, terkait pemanggilan notaris selanjutnya diatur dalam Pasal 66 Undang-Undang Nomor 2 Tahun 2014 tentang Perubahan Undang-Undang Nomor 30 Tahun 2014 tentang Jabatan Notaris

${ }^{1}$ Habib Adjie, Memahami Majelis Pengawas dan Majelis Kehormatan Notaris, (Bandung: Refika Aditama, 2017), hlm 9. 
Otentik's: Jurnal Hukum Kenotariatan (Vol 2, No. 2, Juli 2020)

p-ISSN 2655-5131 e-ISSN 2685-3612

Pasal 66 A Undang-Undang Nomor 2 Tahun 2014 tentang Perubahan Atas UndangUndang Nomor 30 Tahun 2004 tentang Jabatan Notaris dengan menciptakan institusi baru dengan fungsi yang sama, yaitu Majelis Kehormatan Notaris (MKN), mengenai tugas dan fungsi MKN disebutkan dalam Pasal 17 dan Pasal 18 Peraturan Menteri Hukum dan Hak Asasi Manusia Republik Indonesia Nomor 40 Tahun 2015 tentang Susunan Organisasi, Tata Kerja Pengangkatan Anggota, Pemberhentian Anggota, Dan Tata Kerja Majelis Pengawas, Pasal 17 ayat (1) tugas Majelis Kehormatan Notaris Pusat (MKNP) yaitu melaksanakan pembinaan terhadap Majelis Kehormatan Wilayah yang berkaitan dengan tugasnya dan Pasal 17 ayat (2) fungsi MKNP yaitu: melakukan pengawasan terhadap MKN Wilayah. ${ }^{2}$

Dengan demikian tugas MKN Pusat hanya melaksanakan pembinaan terhadap MKN Wilayah dan mempunyai Fungsi pengawasan (supervisi) terhadap MKN Wilayah. Lalu dalam Pasal 18 ayat (1) Peraturan Menteri Hukum dan Hak Asasi Manusia Republik Indonesia Nomor 40 Tahun 2015 tentang Susunan Organisasi, Tata Kerja Pengangkatan Anggota, Pemberhentian Anggota, Dan Tata Kerja Majelis Pengawas, tugas Majelis Kehormatan Notaris Wilayah, yaitu melakukan pemeriksaan terhadap permohonan yang diajukan oleh penyidik, penuntut umum, dan hakim; dan memberikan persetujuan atau penolakan terhadap permintaan persetujuan pemanggilan Notaris untuk hadir dalam proses penidikan, penuntutan, dan proses peradilan. ${ }^{3}$

Dalam Pasal 12 Anggaran Dasar Ikatan Notaris Indonesia ditegaskan pula kewenangan Dewan Kehormatan Notaris (DKN) yang berbunyi:

1. Dewan Kehormatan mewakili Perkumpulan dalam hal pembinaan, pengawasan dan pemberian sanksi dalam penegakan kode Etik Notaris

2. Dewan Kehormatan mempunyai tugas dan kewenangan untuk:

a. Melakukan bimbingan, pengawasan, pembinaan anggota dalam penegakan dan menjunjung kode etik notaris;

b. Memeriksa dan mengambil keputusan atas dugaan pelanggaran ketentuan kode etik Notaris;

c. Memberikan saran dan pendapat kepada majelis Pengawas dan atau Majelis Kehormatan Notaris atas dugaan pelanggaran kode etik Notaris dan jabatan Notaris.

${ }^{2}$ Ibid., hlm 35.

${ }^{3}$ Ibid., hlm 37-38. 
Otentik's: Jurnal Hukum Kenotariatan (Vol 2, No. 2, Juli 2020)

p-ISSN 2655-5131 e-ISSN 2685-3612

d. Melakukan koordinasi, komunikasi dan berhubungan secara langsung kepada anggota maupun pihak-pihak yang berhubungan dengan pelaksanaan dan penegakan kode etik Notaris;

e. Membuat peraturan dalam rangka penegakan kode etik notaris bersama-sama dengan pengurus pusat.

Menurut Pasal 68 Undang-Undang Nomor 2 Tahun 2014 tentang Perubahan Atas Undang-Undang Nomor 30 Tahun 2004 tentang Jabatan Notaris, bahwa Majelis Pengawas Notaris terdiri atas Majelis Pengawas Daerah (MPD), Majelis Pengawas Wilayah (MPW), dan Majelis Pengawas Pusat (MPP).

Adanya 3 (tiga) Intitusi yang mengawasi notaris dengan kewenangan yang berbeda terhadap pelaksanaan tugas jabatannya, dengan maksud agar para notaris wajib memenuhi semua ketentuan dalam melaksanakan tugas jabatannya sehingga akta yang dibuat oleh dan dihadapan notaris dapat terjaga otensitasnya sebagai alat bukti tertulis yang lengkap dan sempurna.

Pengawasan perilaku dan kinerja notaris sekurang-kurangnya sudah dijaga melalui Undang-Undang Nomor 2 Tahun 2014 tentang Perubahan Atas Undang-Undang Nomor 30 Tahun 2004 tentang Jabatan Notaris, Kode Etik Notaris, dan Anggaran Dasar/Anggaran Rumah Tangga Notaris, serta Peraturan Menteri Hukum dan Hak Asasi Manusia Republik Indonesia Nomor 40 Tahun 2015 tentang Susunan Organisasi, Tata Kerja Pengangkatan Anggota, Pemberhentian Anggota, Dan Tata Kerja Majelis Pengawas. Akan tetapi fakta menunjukkan masih banyak juga notaris yang melakukan pelanggaran.

Meskipun telah ada aturan dan institusi yang melakukan pengawasan terhadap pelaksanaan jabatan notaris akan tetapi masih saja notaris terjerat masalah terkait dengan akta-akta yang dibuatnya.

Hal ini dapat dilihat dari banyaknya laporan dari masyarakat yang masuk kepada Majelis Pengawas Notaris di Provinsi Jawa Bawat, pada tahun 2018 terdapat 24 (dua puluh empat) laporan dengan rincian 15 (laporan) laporan diputus dengan sanksi peringatan tertulis, 3 (tiga) laporan diputus tidak terbukti melanggar jabatan, 3 (tiga) laporan diputus dengan sanksi pemberhentian sementara selama 3 (tiga) bulan, dan 3 (tiga) laporan yang disarankan lapor ke Majelis Pengawas Pejabat Pembuat Akta Tanah (MPPPAT) sedangkan sejak bulan Januari hingga Juni tahun 2019 terjadi penurunan menjadi 5 (lima) laporan yang 
masuk dengan rincian 3 (tiga) laporan diputus dengan sanksi peringatan tertulis, 1 (satu) laporan diputus dengan sanksi pemberhentian sementara selama 3 (tiga) bulan dan 1 (satu) laporan diputus dengan sanksi pemberhentian sementara selama 6 (enam) bulan.

Dalam pelaksanaan pengawasan yang dilakukan oleh MPN harus berdasarkan dengan Undang-Undang Nomor 2 Tahun 2014 tentang Perubahan Atas Undang-Undang Nomor 30 Tahun 2004 tentang Jabatan Notaris dan Peraturan Menteri Hukum dan Hak Asasi Manusia Republik Indonesia Nomor 40 Tahun 2015 tentang Susunan Organisasi, Tata Kerja Pengangkatan Anggota, Pemberhentian Anggota, Dan Tata Kerja Majelis Pengawas akan tetapi dalam proses pengawasan dengan cakupan wilayah yang luas menjadi masalah tersendiri bagi majelis pengawas mengingat jumlah notaris yang akan diawasi berbanding jauh dengan jumlah majelis pengawas yang melakukan pengawasan, untuk Provinsi Jawa Barat sendiri terdapat 3896 (tiga ribu delapan ratus Sembilan puluh enam) notaris dan khusus Kabupaten Bandung sebanyak 422 (empat ratus dua puluh dua) notaris serta kota Bandung sebanyak 238 (dua tiga puluh delapan) notaris.

Dalam hal adanya laporan masyarakat terhadap dugaan pelanggaran yang dilakukan oleh notaris maka akan diperiksa oleh MPD, hasil pemeriksaan MPD selanjutnya merekomendasikan terhadap adanya dugaan pelanggaran Kode Etik maupun UUJN kepada MPW, MPW akan menyelenggarakan sidang dengan memanggil pihak pelapor dan pihak terlapor akan tetapi sering kali pihak pelapor dan pihak terlapor tidak menghadiri persidangan, walaupun telah dilakukan upaya pemanggilan dari MPN. Hal ini menjadi kendala-kendala bagi MPN dalam melaksanakan kewenangannya untuk memeriksa dan memutus terhadap dugaan pelanggaran tugas dan kewenangan notaris.

\section{LANDASAN TEORI}

\section{a. Teori Peran}

Di dalam Kamus Umum Bahasa Indonesia, bahwa "Peran adalah sesuatu yang jadi bagian atau yang memegang pimpinan yang terutama". Selanjutnya "Peran adalah bentuk dari perilaku yang diharapkan dari seseorang pada situasi sosial tertentu".

\footnotetext{
${ }^{4}$ W.J.S. Poerwadarminto, Kamus Umum Bahasa Indonesia, (Jakara: PN Balai Pustaka, 1984), hlm 735. ${ }^{5}$ Ibid.
} 
Peranan adalah suatu sistem atau kaidah-kaidah yang berisikan patokan patokan perilaku, pada kedudukan kedudukan tertentu di dalam masyarakat kedudukan tersebut dimiliki oleh pribadi atau kelompok yang peranannya memegang peranan tersebut dapat sesuatu mungkin perlawanan dengan apa yang ditentukan dalam kaidah-kaidah. ${ }^{6}$

Peranan yang sebenarnya dilakukan dinamakan Role performance atau role playing. ${ }^{7}$ Peranan dalam hal ini adalah tindakan atau perbuatan yang diharapkan oleh seseorang atau kelompok kepada seseorang atau kelompok yang berdasarkan kedudukannya dapat memberikan sebuah pengaruh terhadap lingkungan tersebut.

Berdasarkan uraian di atas dapat diketahui bahwa peranan merupakan seperangkat norma atau aturan yang berisi kewajiban yang dimiliki oleh seseorang dalam menjalankan dan melaksanakan tugas serta kedudukannya pada tingkat sosial masyarakat. Peranan yang melekat pada diri seseorang harus dibedakan dengan posisi dalam pergaulan masyarakat. Posisi seseorang dalam masyarakat merupakan unsur statis yang menunjukkan tempat individu dalam masyarakat.

Peranan diungkapkan oleh Soerjono Soekanto bahwa "Peranan merupakan aspek dinamis kedudukan (status). Apabila seseorang melaksanakan hak dan kewajibannya sesuai dengan kedudukannya, maka ia menjalankan suatu peranan"8.

Pendapat lain dikemukakan oleh Livinson yang dikutip oleh Soerjono Soekanto bahwa: ${ }^{9}$

1) Peranan meliputi norma-norma yang diungkapkan dengan posisi atau tempat seseorang dalam masyarakat.

2) Peranan adalah suatu konsep tentang apa yang dilakukan oleh individu dalam masyarakat sebagai organisasi,

3) Peranan juga dapat dikatakan sebagai perilaku individu yang penting sebagai struktur sosial masyarakat.

\section{b. Teori Pengawasan}

Pengawasan dapat diartikan sebagai proses untuk menjamin bahwa tujuan organisasi dan manajemen tercapai. Ini berkenaan dengan cara-cara membuat kegiatan-kegiatan sesuai yang di rencanakan dengan instruksi yang telah diberikan dan dengan prinsip-prinsip yang

\footnotetext{
${ }^{6}$ Soerjono Soekanto, Pokok-pokok Sosiologi Hukum, (Jakarta: Grafindo Persada, 2003), hlm 193.

${ }^{7}$ Poerwadarinta , Kamus Umum Bahasa Indonesia, (Jakarta:Balai Pustaka, 1995), hlm 751.

${ }^{8}$ Soerjono Soekanto, Sosiologi Suatu Pengantar, (Jakarta: Grafindo Persada, 1990), hlm 268.

${ }^{9}$ Ibid., hlm 221.
} 
telah digariskan. Menurut Robert J. M Ockler, unsur-unsur esensial proses pengawasan bahwa "suatu usaha sistematika untuk menetapkan standar pelaksanaan dan tujuan-tujuan perencanaan merancang sistem informasi, umpan balik, membandingkan kegiatan nyata dengan standar yang telah ditetapkan sebelumnya" ${ }^{\prime 10}$.

Menurut Sarwoto definisi pengawasan adalah "kegiatan manajer yang mengusahakan agar pekerjaan-pekerjaan terlaksana sesuai dengan rencana yang ditetapkan dan atau hasil yang dikehendaki" $"$.

Menurut Manullang bahwa "Pengawasan yakni suatu proses untuk menetapkan pekerjaan sesuai dengan rencana semula" ${ }^{\prime 2}$.

Kemudian menurut Henry Fayol mengatakan bahwa

"pengawasan terdiri dari pengujian apakah segala sesuatu berlangsung sesuai dengan rencana yang telah ditentukan dengan intruksi yang telah digariskan, bertujuan untuk menunjukan (menentukan) kelemahan-kelemahan dan kesalahankesalahan dengan maksud untuk memperbaikinya dan mencegah terulangnya kembali". ${ }^{13}$

Pengawasan adalah suatu bentuk pola pikir dan pola tindakan untuk memberikan pemahaman dan kesadaran kepada seseorang atau beberapa orang yang diberikan tugas untuk dilaksanakan dengan menggunakan berbagai sumber daya yang tersedia secara baik dan benar, sehingga tidak terjadi kesalahan dan penyimpangan yang sesunagguhnya dapat menciptakan kerugian oleh lembaga atau organisasi yang bersangkutan. ${ }^{14}$

Menurut Handayaningrat Pengawasan ialah "suatu proses dimana pimpinan ingin mengetahui apakah hasil pelaksanaan pekerjaan yang dilakukan oleh bawahannya sesuai dengan rencana, perintah, tujuan atau kebijaksanaan yang telah ditentukan"15.

a. Maksud dan Tujuan Pengawasan

Maksud dan tujuan pengawasan menurut Handayaningrat adalah $:{ }^{16}$

\footnotetext{
${ }^{10}$ Hani Handoko, Manajemen Personalia dan Sumber Daya Manusia (Jakarta: Rafika Aditam, 1999), hlm 360.

${ }^{11}$ Sarwoto, Dasar-Dasar Organisasi dan Management, (Jakarta: Ghalia Indonesia, 2010), hlm 93.

${ }^{12}$ M. Manullang, Dasar-Dasar Management, (Jakarta: Ghalia Indonesia, 1977), hlm 136.

${ }^{13}$ Victor M. Situmorang, Jusuf Juhir, Aspek Hukum Pengawasan Melekat, (Jakarta, Rineka Cipta, 1994), hlm 20.

${ }^{14}$ Makmur, Efektivitas Kebijakan Pengawasan, (Bandung: Refika Aditama, 2011), hlm 176.

${ }^{15}$ Ibid.

${ }^{16}$ Ibid.
} 
1) Untuk mencegah atau memperbaiki kesalahan, penyimpangan, ketidaksesuaian penyelenggaraan yang lain-lain yang tidak sesuai dengan tugas dan wewenang yang telah ditentukan.

2) Agar hasil pelaksanaan pekerjaan diperoleh secara berdaya guna dan berhasil guna sesuai dengan rencana yang telah ditentukan sebelumnya.

b. Prinsip-Prinsip Pengawasan Handayaningrat mengemukakan bahwa: ${ }^{17}$

1) Pengawasan berorientasi pada tujuan organisasi

2) Pengawasan harus obejktif, jujur dan mendahulukan kepentingan umum.

3) Pengawasan harus berorientasi terhadap kebenaran menurut peraturan perundangundangan yang berlaku, berorientasi terhadap kebenaran tujuan dalam pelaksanaan pekerjaan.

4) Pengawasan harus menjamin sumber daya dan hasil guna pekerjaan.

5) Pengawasan harus berdasarkan atas standar yang objektif, teliti dan tepat.

6) Pengawasan harus bersifat terus menerus.

7) Hasil pengawasan, harus dapat memberikan umpan balik terhadap perbaikan dan penyempurnaan dalam pelaksanaan, perencanaan serta kebijaksanaan waktu yang akan datang.

\section{METODE PENELITIAN}

Penelitian ini akan disusun dengan menggunakan penelitian yuridis normatif, penelitian yuridis normatif yaitu penelitian yang difokuskan untuk mengkaji penerapan kaidah-kaidah atau norma-norma dalam hukum positif. Yuridis Normatif, yaitu pendekatan yang menggunakan konsepsi legis positivis. Konsep ini memandang hukum identik dengan norma-norma tertulis yang dibuat dan diundangkan oleh lembaga atau pejabat yang berwenang. Konsepsi ini memandang hukum sebagai suatu sistem normatif yang bersifat mandiri, tertutup dan terlepas dari kehidupan masyarakat yang nyata.

Penelitian ini menggunakan pendekatan perundang-undangan (statute aproach) dan pendekatan kasus (case aproach). Pendekatan perundang-undangan digunakan untuk mengetahui keseluruhan peraturan hukum khususnya hukum terkait pengawasan terhadap notaris yang dilakukan oleh MPN. Pendekatan kasus bertujuan untuk mepelajari penerapan

\footnotetext{
${ }^{17} \mathrm{Ibid}$.
} 
norma-norma atau kaidah hukum yang dilakukan dalam praktik hukum terutama mengenai kasus-kasus yang terjadi di Provinsi Jawa Barat.

Didalam penelitian, dikenal 3 (tiga) jenis alat pengumpulan data, yaitu studi dokumen atau bahan pustaka, pengamatan atau observasi, dan wawancara atau interview. Dalam penelitian ini peneliti mengunakan tehnik pengumpulan data melalui studi kepustakaan, yaitu mengkaji peraturan perundang-undangan, buku-buku literatur, karya tulis dari ahli hukum dan wawancara.

Dalam menyajikan data agar mudah dipahami, peneliti menggunakan metode penyajian dengan analisis deskriptif, yang merupakan suatu metode untuk mendeskripsikan, menjelaskan, menguraikan, dan menggambarkan data. Data dimaksud yaitu data hasil wawancara di lapangan yang dilaksanakan dengan informan yaitu Majelis Pengawas Daerah Kota Bandung dan Majelis Pengawas Wilayah Provinsi Jawa Barat kemudian menganalisanya dengan berpedoman pada sumber data hasil wawancara langsung yang dilakukan.

Data yang diperoleh dalam penelitian ini dianalisis dengan menggunakan metode kualitatif yaitu metode analisis data dengan cara mengelompokkan dan menseleksi data yang diperoleh dari penelitian lapangan menurut kualitas dan kebenarannya kemudian disusun secara sistematis, yang selanjutnya dikaji dengan metode berfikir secara deduktif dihubungkan dengan teori-teori dari studi kepustakaan (data sekunder), kemudian dibuat kesimpulan yang berguna untuk menjawab rumusan masalah dalam penelitian ini.

Hasil analisis tersebut dipaparkan secara deskriptif, yaitu cara menggambarkan keadaan sebenarnya di lapangan sehingga diperoleh uraian hasil penelitian yang bersifat deskriptif-kualitatif yang nantinya akan diperoleh arti dan kesimpulan untuk menjawab permasalahan.

\section{HASIL PENELITIAN}

Kewenangan notaris diatur dalam Pasal 15 UUJN bahwa Notaris berwenang membuat Akta autentik mengenai semua perbuatan, perjanjian, dan penetapan yang diharuskan oleh peraturan perundang-undangan dan/atau yang dikehendaki oleh yang berkepentingan untuk dinyatakan dalam Akta autentik, menjamin kepastian tanggal pembuatan Akta, menyimpan Akta, memberikan grosse, salinan dan kutipan Akta, semuanya itu sepanjang pembuatan 
Akta itu tidak juga ditugaskan atau dikecualikan kepada pejabat lain atau orang lain yang ditetapkan oleh undang-undang.

Oleh karena itu kewenangan notaris yang terdapat dalam UUJN, dipisahkan menjadi kewenangan umum dan kewenangan khusus notaris.

Kewenangan umum notaris yaitu membuat akta otentik mengenai semua perbuatan, perjanjian, dan penetapan yang diharuskan oleh peraturan perundang-undangan dan/atau yang dikehendaki oleh yang berkepentingan untuk dinyatakan dalam akta otentik, menjamin kepastian tanggal pembuatan akta, menyimpan akta, memberikan grosse, salinan dan kutipan akta, semuanya itu sepanjang pembuatan akta itu tidak juga ditugaskan atau dikecualikan kepada pejabat lain atau orang lain yang ditetapkan oleh Undang-Undang.

Dan akta otentik sebagai akta yang mempunyai kekuatan hukum pembuktian yang sempurna dan mengikat bagi para pihak, sehingga dalam pembuktiannya dapat berdiri sendiri dan tidak perlu mendapat bantuan dan tambahan dari alat bukti yang lain, kecuali apabila ada pihak lawan yang dapat membuktikan akta tersebut tidak benar dengan akta otentik lainnya, maka kekuatan pembuktian akta otentik dapat berkurang, sehingga perlu mendapat bantuan alat bukti tambahan lainnya.

Kewenangan khusus notaris lainnya di atur dalam Pasal 51 UUJN, yaitu berwenang untuk membetulkan kesalahan tulisan, atau kesalahan ketik yang terdapat dalam minuta akta yang telah ditandatangani, dengan cara membuat berita acara pembetulan tersebut dan notaris wajib menyampaikannya kepada para pihak.

Peran Majelis Pengawas Notaris Jawa Barat Dalam Menjalankan Kewenangan Terhadap Laporan Masyarakat Sejak kehadiran institusi Notaris di Indonesia, pengawasan terhadap notaris selalu dilakukan oleh lembaga peradilan dan pemerintah, bahwa tujuan dari pengawasan agar para notaris ketika menjalankan tugas jabatannya memenuhi semua persyaratan yang berkaitan dengan pelaksanaan tugas jabatan notaris, demi untuk pengamanan dari kepentingan masyarakat, karena notaris diangkat oleh pemerintah, bukan untuk kepentingan diri notaris sendiri, tapi untuk kepentingan masyarakat yang dilayaninya.

Sebelum diberlakukannya UUJN, pengawasan dan penjatuhan sanksi dilakukan oleh Pengadilan Negeri. Setelah adanya reformasi birokrasi di lingkungan Mahkamah Agung dan berdasarkan aturan tersebut, maka Mahkamah Agung hanya mempunyai kewenangan dalam lingkup peradilan. Maka sejak diadakan pembatasan terhadap kewenangan Mahkamah 
Agung tersebut, pengawasan terhadap notaris yang semula di atur dalam Pasal 54 UndangUndang Nomor 8 Tahun 2004 tentang Pengadilan Negeri dicabut melalui Pasal 91 UUJN, sehingga kewenangan untuk melakukan pengawasan, pemeriksaan, penjatuhan sanksi, dan pembinaan terhadap notaris dilakukan oleh Menteri Hukum dan Hak Asasi Manusia dengan cara membentuk Majelis Pengawas.

Dalam Pasal 67 UUJN, kewenangan untuk melakukan pengawasan notaris dilakukan oleh Menteri. Dalam melaksanakan pengawasan terhadap notaris, maka Menteri membentuk Majelis Pengawas yang merupakan perpanjangan tangan dari Menteri untuk melaksanakan tugas pengawasan terhadap kinerja notaris yang ada di wilayah Indonesia.

Tujuan dari pengawasan agar para notaris ketika menjalankan jabatannya memenuhi semua persyaratan yang berkaitan dengan pelaksanaan tugas jabatan notaris, demi untuk pengamanan kepentingan masyarakat. Hal ini dikarenakan notaris diangkat oleh pemerintah bukan untuk kepentingan diri notaris sendiri, melainkan untuk kepentingan masyarakat yang dilayaninya.

Tujuan lain pengawasan terhadap notaris, bahwa notaris dihadirkan untuk melayani kepentingan masyarakat yang membutuhkan alat bukti berupa akta otentik sesuai keinginan para pihak kepada notaris.

Pengawasan yang dilakukan oleh MPN tidak hanya pelaksanaan tugas jabatan notaris agar sesuai dengan ketentuan UUJN, tapi juga Kode Etik Notaris dan tindak tanduk atau perilaku kehidupan notaris yang dapat mencederai keluhuran martabat jabatan notaris dalam pengawasan majelis pengawas. Hal ini menunjukkan sangat luas ruang lingkup pengawasan yang dilakukan oleh majelis pengawas.

Ada 3 (tiga) intitusi yang mengawasi notaris dengan kewenangan yang berbeda terhadap pelaksanaan tugas jabatannya, dengan maksud agar para notaris wajib memenuhi semua ketentuan dalam melaksanakan tugas jabatannya sehingga akta yang dibuat oleh dan dihadapan notaris dapat terjaga otensitasnya sebagai alat bukti tertulis yang lengkap dan sempurna, dan pengawasan perilaku dan kinerja notaris sekurang-kurangnya juga sudah dijaga melalui UUJN dan Kode Etik akan tetapi fakta menunjukkan masih banyak juga notaris yang melakukan pelanggaran. 
Meskipun telah ada aturan dan institusi yang melakukan pengawasan terhadap pelaksanaan jabatan notaris akan tetapi masih saja banyak laporan dari masyarakat terhadap notaris terkait dengan akta-akta yang dibuatnya.

Menurut penulis hal ini tidak sejalan dengan teori pengawasan menurut Robert J. M Ockler dan Manullang, menurut Robert J. M Ockler bahwa pengawasan adalah suatu usaha sistematika untuk menetapkan standar pelaksanaan dan tujuan-tujuan perencanaan dengan standar yang telah ditetapkan sebelumnya sedangkan menurut Manullang bahwa Pengawasan yakni suatu proses untuk menetapkan pekerjaan sesuai dengan rencana semula, dalam pelaksanaan pengawasan MPN melakukan pengawasan agar dalam pelaksanaan tugas jabatan notaris selalu sesuai dengan Kode Etik dan UUJN pengawasan ini dilakukan agar tindakan yang dilakukan notaris dalam melaksanakan tugas dan kewenangannya tidak disalahgunakan diluar batas kewajaran yang bertentangan dengan Kode Etik maupun UUJN.

Menurut penulis, MPN memiliki peran yang sangat penting agar pelaksanaan tugas jabatan notaris sesuai dengan ketentuan UUJN dan Kode Etik, sejalan dengan teori peran menurut Bruce J. Cohen bahwa MPN memiliki peran nyata dalam melakukan pengawasan terhadap notaris agar notaris dalam melaksanakan tugas jabatannya tidak menyimpang, akan tetapi berdasarkan fakta dilapangan hal ini justru bertentangan karena dari tahun 2018 hingga Juni 2019 terdapat 29 (dua puluh sembilan) laporan yang masuk di MPN Provinsi Jawa Barat, salah satu laporan yang masuk tanggal 19 Februari 2019, yaitu terkait akta RUPS yang dibuat oleh seorang notaris selaku terlapor, menurut keterangan pelapor bahwa dalam pembuatan akta RUPS tersebut, pelapor tidak mengetahui dan tidak mengikuti RUPS yang tercatat dalam akta tersebut, sedangkan dalam akta tersebut tertulis bahwa pelapor menghadap kepada notaris.

Hasil pemeriksaan MPD Kota Bandung yang dituangkan dalam BAP Nomor: 02/BAP/MPDN Kota Bandung/III/2019 tanggal 28 Februari 2019, ditemukan fakta hukum bahwa diduga adanya pelanggaran Kode Etik dan UUJN yang dilakukan oleh notaris tersebut/terlapor. Sehingga MPD merekomendasikan untuk penanganan selanjutnya termasuk mengenai pemberian sanksi yang akan dijatuhkan kepada notaris tersebut diserahkan kepada MPW Jawa Barat. 
Selanjutnya hasil pemeriksaan oleh MPD dikirimkan kepada MPW, berdasarkan surat penyampaian Nomor 27/MPDN Kota Bandung/III/2019, setelah hasil pemeriksaan diterima oleh MPW, MPW akan menindaklanjuti sesuai kewenangan MPW.

Pemeriksaan terhadap laporan masyarakat yang dilakukan oleh MPN mulai dari pengajuan laporan hingga upaya hukum telah diatur dalam Peraturan Menteri Hukum dan Hak Asasi Manusia Republik Indonesia Nomor M.02.PR08.10 Tahun 2004 tentang Tata Cara Pengangkatan Anggota, Pemberhentian Anggota, Susunan Organisasi, Tata Kerja dan Tata Cara Pemeriksaan Majelis Pengawas Notaris, sebagai berikut:

Dalam pengajuan laporan telah di atur dalam Pasal 21 Peraturan Menteri Hukum dan Hak Asasi Manusia Republik Indonesia Nomor: M.02.PR.08.10 Tahun 2004 tentang Tata Cara Pengangkatan Anggota, Pemberhentian Anggota, Susunan Organisasi, Tata Kerja, dan Tata Cara Pemeriksaan Majelis Pengawas Notaris, yaitu:

1. Laporan dapat diajukan oleh pihak yang merasa dirugikan.

2. Laporan harus disampaikan secara tertulis dalam bahasa Indonesia disertai bukti-bukti yang dapat dipertanggungjawabkan.

3. Laporan tentang adanya dugaan pelanggaran Kode Etik Notaris atau pelanggaran pelaksanaan jabatan notaris disampaikan kepada MPD.

4. Laporan masyarakat selain sebagaimana dimaksud disampaikan kepada MPW..

5. Dalam hal laporan sebagaimana dimaksud disampaikan kepada MPW, maka MPW meneruskan kepada MPD yang berwenang.

6. Dalam hal laporan sebagaimana dimaksud disampaikan kepada MPP, maka MPP meneruskannya kepada MPD yang berwenang.

Selanjutnya setelah laporan diterima akan dilakukan pemanggilan, adapun proses pemanggilan telah diatur dalam Pasal 22 Peraturan Menteri Hukum dan Hak Asasi Manusia Republik Indonesia Nomor: M.02.PR.08.10 Tahun 2004 tentang Tata Cara Pengangkatan Anggota, Pemberhentian Anggota, Susunan Organisasi, Tata Kerja, dan Tata Cara Pemeriksaan Majelis Pengawas Notaris, yaitu:

Ketua Majelis Pemeriksa melakukan pemanggilan terhadap pelapor dan terlapor.

1. Pemanggilan dilakukan dengan surat oleh sekretaris dalam waktu paling lambat 5 (lima) hari kerja sebelum sidang. 
2. Dalam keadaan mendesak pemanggilan sebagaimana dimaksud dapat dilakukan melalui faksimili yang segera disusul dengan surat pemanggilan.

3. Dalam hal terlapor setelah dipanggil secara sah dan patut, tetapi tidak hadir maka dilakukan pemanggilan kedua.

4. Dalam hal terlapor setelah dipanggil secara sah dan patut yang kedua kali namun tetap tidak hadir maka pemeriksaan dilakukan dan putusan diucapkan tanpa kehadiran terlapor.

5. Dalam hal pelapor setelah dipanggil secara sah dan patut tidak hadir, maka dilakukan pemanggilan yang kedua, dan apabila pelapor tetap tidak hadir maka Majelis Pemeriksa menyatakan laporan gugur dan tidak dapat diajukan lagi.

Pemeriksaan pertama kali dilakukan oleh MPD, sebagaimana diatur dalam Pasal 23

Peraturan Menteri Hukum dan Hak Asasi Manusia Republik Indonesia Nomor: M.02.PR.08.10 Tahun 2004 tentang Tata Cara Pengangkatan Anggota, Pemberhentian Anggota, Susunan Organisasi, Tata Kerja, dan Tata Cara Pemeriksaan Majelis Pengawas Notaris, yaitu:

1. Pemeriksaan oleh MPD tertutup untuk umum.

2. Pemeriksaan dimulai dalam jangka waktu paling lambat 7 (tujuh) hari kalender setelah laporan diterima.

3. MPD harus sudah menyelesaikan pemeriksaan dan menyampaikan hasil pemeriksaan dalam jangka waktu paling lambat 30 (tiga puluh) hari kalender terhitung sejak laporan diterima.

4. Hasil pemeriksaan sebagaimana dimaksud dituangkan dalam BAP yang ditandatangani oleh ketua dan sekretaris.

5. Surat pengantar pengiriman BAP yang dikirimkan kepada MPW ditembuskan kepada pelapor, terlapor, MPP, dan Pengurus Daerah Ikatan Notaris Indonesia.

6. Pada sidang pertama yang ditentukan, pelapor dan terlapor hadir, lalu MPD melakukan pemeriksaan dengan membacakan laporan dan mendengar keterangan pelapor.

7. Dalam pemeriksaan sebagaimana dimaksud pada ayat (1) terlapor diberi kesempatan yang cukup untuk menyampaikan tanggapan.

8. Pelapor dan terlapor dapat mengajukan bukti-bukti untuk mendukung dalil yang diajukan.

9. Laporan diperiksa oleh MPD dalam jangka waktu paling lambat 30 (tiga puluh) hari kalender terhitung sejak laporan diterima. 
Setelah MPW menerima laporan dari MPD selanjutnya MPW melakukan pemeriksaan hal ini sebagaimana di atur dalam Peraturan Menteri Hukum dan Hak Asasi Manusia Republik Indonesia Nomor: M.02.PR.08.10 Tahun 2004 tentang Tata Cara Pengangkatan Anggota, Pemberhentian Anggota, Susunan Organisasi, Tata Kerja, dan Tata Cara Pemeriksaan Majelis Pengawas Notaris, yaitu:

1. Pemeriksaan oleh MPW tertutup untuk umum.

2. Putusan diucapkan dalam sidang yang bersifat terbuka untuk umum.Dalam hal terdapat perbedaan pendapat di antara sesama MPW, maka perbedaan pendapat tersebut dimuat dalam putusan.

3. MPW mulai melakukan pemeriksaan terhadap hasil pemeriksaan MPD dalam jangka waktu paling lambat 7 (tujuh) hari kalender sejak berkas diterima.

4. MPW berwenang memanggil pelapor dan terlapor untuk didengar keterangannya.

5. Putusan diucapkan dalam jangka waktu paling lambat 30 (tiga puluh) hari kalender sejak berkas diterima.

6. Putusan sebagaimana dimaksud harus memuat alasan dan pertimbangan yang cukup, yang dijadikan dasar untuk menjatuhkan putusan.

7. Putusan sebagaimana dimaksud pada ayat (1) ditandatangani oleh Ketua, Anggota, dan Sekretaris MPW.

8. Dalam hal laporan tidak dapat dibuktikan, maka MPW mengucapkan putusan yang menyatakan laporan ditolak dan terlapor direhabilitasi nama baiknya.

9. Dalam hal laporan dapat dibuktikan, maka terlapor dijatuhi sanksi sesuai dengan tingkat pelanggaran yang dilakukan.

10. Salinan putusan MPW disampaikan kepada Menteri, pelapor, terlapor, MPD, dan Pengurus Pusat Ikatan Notaris Indonesia, dalam jangka waktu paling lambat 30 (tiga puluh) hari kalender terhitung sejak putusan diucapkan.

Menurut Deden Firmansyah , ada beberapa hal yang menjadi alasan banyaknya notaris yang terjerat kasus hukum, antara lain karena masih ada oknum notaris yang berperilaku menyimpang, melakukan kesalahan berkali-kali tanpa ada itikad untuk memperbaiki, ada yang karena faktor persaingan dan ada juga memang karena mafia serta ada juga notaris yang mau di manfaatkan. 
Otentik's: Jurnal Hukum Kenotariatan (Vol 2, No. 2, Juli 2020)

p-ISSN 2655-5131 e-ISSN 2685-3612

Kewenangan MPD diatur dalam Pasal 70 dan 71 UUJN dan Pasal 23 ayat (1) huruf f dan ayat (2) huruf g Peraturan Menteri Hukum dan Hak Asasi Manusia Republik Indonesia Nomor 40 Tahun 2015 tentang Susunan Organisasi, Tata Kerja Pengangkatan Anggota, Pemberhentian Anggota, Dan Tata Kerja Majelis Pengawas.

Sebelum dibatalkannya Pasal 66 UUJN, notaris melalui MPD mempunyai hak ingkar untuk tidak hadir dalam pemeriksaan yang berkaitan dengan akta yang dibuatnya atau protokol notaris yang berada dalam penyimpanannya.

Kewenangan ini sebelumnya tidak diberikan kepada MPW ataupun MPP. Setelah dibatalkannya Pasal 66 UUJN tersebut, maka kewenangan tersebut menjadi kewenangan Majelis Kehormatan Notaris sebagaimana yang terdapat di dalam Pasal 66 UUJN.

Terkait laporan masyarakat MPN memiliki peran terhadap kewenangan dan kewajiban masing-masing sebagaimana diatur dalam UUJN dan Peraturan Menteri Hukum dan Hak Asasi Manusia Republik Indonesia Nomor M.02.PR08.10 Tahun 2004 tentang Tata Cara Pengangkatan Anggota, Pemberhentian Anggota, Susunan Organisasi, Tata Kerja dan Tata Cara Pemeriksaan Majelis Pengawas Notaris Jo Peraturan Menteri Hukum dan Hak Asasi Manusia Republik Indonesia Nomor 40 Tahun 2015 tentang Susunan Organisasi, Tata Kerja Pengangkatan Anggota, Pemberhentian Anggota, Dan Tata Kerja Majelis Pengawas, sebagai berikut:

Secara garis besar kewenangan MPD terdapat dalam Pasal 70 UUJN yaitu sebagai berikut:

1. Menerima laporan dari masyarakat mengenai adanya dugaan pelanggaran kode etik notaris atau pelanggaran pelaksanaan jabatan notaris..

2. Menyelenggarakan sidang untuk memeriksa adanya dugaan pelanggaran kode etik notaris atau pelanggaran pelaksanaan jabatan notaris.

3. Membuat dan menyampaikan laporan sebagaimana dimaksud MPW.

Selain kewenangan, MPD juga memiliki kewajiban dalam hal adanya laporan masyarakat yang masuk yang harus dilaksanakan oleh MPD, sebagaimana diatur dalam Pasal 71 UUJN, yaitu:

1. Memeriksa laporan masyarakat terhadap notaris dan menyampaikan hasil pemeriksaan tersebut kepada MPW dalam waktu 30 (tiga puluh) hari, dengan tembusan kepada pihak yang melaporkan, notaris yang bersangkutan, MPP, dan Organisasi Notaris. 
2. Membuat BAP dan menyampaikannya kepada Majelis Pengawas Wilayah setempat, dengan tembusan kepada notaris yang bersangkutan, Organisasi Notaris, dan Majelis Pengawas Pusat.

3. Merahasiakan isi akta dan hasil pemeriksaan.

Selain di dalam UUJN, kewenangan MPD terhadap laporan masyarakat yang masuk di atur dalam Pasal 23 ayat (1) huruf $f$ dan ayat(2) huruf g Peraturan Menteri Hukum dan Hak Asasi Manusia Republik Indonesia Nomor 40 Tahun 2015 tentang Susunan Organisasi, Tata Kerja Pengangkatan Anggota, Pemberhentian Anggota, Dan Tata Kerja Majelis Pengawas, yaitu:

1. Menerima laporan dari masyarakat mengenai adanya dugaan pelanggaran kode etik Notaris atau pelanggaran ketentuan dalam Undang-Undang.

2. Memanggil Notaris untuk hadir dalam pemeriksaan yang berkaitan dengan akta yang dibuatnya atau protokol Notaris yang berada dalam penyimpanan Notaris.

Sedangkan kewenangan MPW di atur dalam Pasal 73 UUJN dan Selain itu MPW memiliki kewajiban yang harus dilaksanakannya, sesuai dengan Pasal 75 UUJN. Selain di dalam UUJN, kewenangan MPW juga di atur dalam Peraturan Menteri Hukum dan Hak Asasi Manusia Republik Indonesia Nomor 40 Tahun 2015 tentang Susunan Organisasi, Tata Kerja Pengangkatan Anggota, Pemberhentian Anggota, Dan Tata Kerja Majelis Pengawas. Adapun kewenangan MPW yang terdapat dalam Pasal 24 huruf c bahwa MPW berwenang menerima laporan dari masyarakat mengenai adanya dugaan pelanggaran kode etik Notaris atau pelanggaran ketentuan dalam Undang-Undang.

Menurut penulis seharusnya dalam hal pemeriksaan laporan masyarakat yang dilakukan oleh MPD, MPD diberi kewenangan lebih untuk memutuskan dan memberi sanksi kepada terlapor yang telah terbukti melakukan pelanggaran terhadap Kode Etik dan UUJN, karena dalam sidang pemeriksaan yang dilakukan oleh MPW pihak pelapor maupun terlapor sering tidak taat aturan yaitu tidak menghadiri sidang, hal ini dipertegas dengan penyataan Wira Franciska selaku Majelis Pengawas Wilayah Provinsi Jawa Barat, Menurut Wira Franciska, terkait laporan masyarakat pihak pelapor dan pihak terlapor sering tidak memenuhi pemanggilan dalam persidangan yang telah ditentukan oleh MPW.

Apabila segala prosedur pemanggilan sudah dilakukan menurut aturan yang telah ditetapkan. Apabila pihak terlapor tidak hadir dalam persidangan, maka persidangan tetap 
Otentik's: Jurnal Hukum Kenotariatan (Vol 2, No. 2, Juli 2020)

p-ISSN 2655-5131 e-ISSN 2685-3612

berlanjut dan putusan persidangan akan diputus secara verstek. Apabila putusan MPW dalam persidangan telah diputus, maka notaris dapat mengajukan upaya hukum banding kepada MPP yang diberi waktu selama 7 (tujuh) hari kalender.

Kendala-Kendala Majelis Pengawas Notaris Jawa Barat Dalam Melakukan Pengawasan Kode Etik notaris merupakan pengaturan yang berlaku untuk anggota organisasi notaris, jika terjadi pelanggaran atas kode etik notaris tersebut, maka organisasi notaris melalui Dewan Kehormatan Notaris berkewajiban untuk memeriksa notaris dan menyelenggarakan sidang pemeriksaan atas pelanggaran tersebut, dan jika terbukti, DKN dapat memberikan sanksi atas keanggotaan yang bersangkutan pada organisasi jabatan notaris.

Pelanggaran atas kode etik notaris harus diperiksa oleh DKN sendiri tidak perlu diberikan kepada majelis pengawas sehingga jika majelis pengawas menerima laporan telah terjadi pelanggaran kode etik notaris, sangat tepat jika laporan seperti diteruskan kepada DKN untuk diperiksa dan diberikan sanksi oleh DKN atau dalam hal ini Majelis Pengawas harus memilah dan memilih laporan yang menjadikan kewenangannya untuk diperiksa dan laporan yang menjadi kewenangan DKN.

Kehormatan organisasi notaris salah satunya yaitu dapat mengontrol perilaku para anggotanya sendiri dan memberikan sanksi kepada yang terbukti melanggar, berdasarkan Pasal 70 UUJN Majelis Pengawas juga diberi wewenang untuk menyelenggarakan sidang adanya dugaan pelanggaran kode etik notaris. Menurut penulis, pemberian wewenang itu telah memberikan peran yang besar kepada Majelis Pengawas, dengan adanya pemberian wewenang seperti itu kepada MPN merupakan suatu bentuk pengambilalihan wewenang dari DKN.

Peran MPN di Jawa Barat saat ini hanya melakukan pembinaan administrasi dan pengawasan administrasi yang dilakukan 1 (satu) kali dalam 1 (satu) tahun, MPN akan berkeliling untuk memeriksa protokol notaris dan keadaan kantornya, dan untuk saat ini hanya bisa dilakukan 1 (satu) kali, dan dalam 1 (satu) hari itu MPN hanya memeriksa maksimal 4 (empat) notaris, dan karena setiap anggota majelis memiliki pekerjaan pokok, jadi anggota MPN harus menjadwalkan waktu dalam melakukan pemeriksaaan agar bisa menyesuaikan dengan jadwal yang tidak begitu padat dengan pekerjaan masing-masing 
setiap anggota MPN, dan MPN akan memberikan pemberitahuan 7 (tujuh) hari sebelum melakukan pengawasan.

Menurut Pasal 70 huruf b UUJN menentukan bahwa MPD berwenang melakukan pemeriksaan terhadap Protokol Notaris secara berkala 1 (satu) kali dalam 1 (satu) tahun atau setiap waktu yang dianggap perlu. Majelis atau Tim Pemeriksa dengan tugas seperti ini hanya ada pada MPD, yang merupakan tugas pemeriksaan rutin atau setiap waktu yang diperlukan dan langsung dilakukan di kantor Notaris yang bersangkutan. Tim Pemeriksa ini sifatnya insidentil (untuk pemeriksaan tahunan atau sewaktu-waktu), dibentuk oleh MPD jika diperlukan. Pemeriksaan yang dilakukan Tim Pemeriksa.

Selanjutnya dalam Pasal 20 ayat (1) Peraturan Menteri Hukum Dan Hak Asasi Manusia Republik indonesia Nomor: M.02.PR.08.10 Tahun 2004 tentang Tata Cara Pengangkatan Anggota, Pemberhentian Anggota, Susunan Organisasi, Tata kerja, dan Tata Cara Pemeriksaan Majelis Pengawas Notaris, yaitu:

1. Dalam melakukan pemeriksaan terhadap Notaris, Ketua Majelis Pengawas Notaris membentuk MPD, MPW, dan MPP dari masing-masing unsur yang terdiri atas 1 (satu) orang ketua dan 2 (dua) orang anggota Majelis Pemeriksa.

2. MPW dan MPP berwenang memeriksa dan memutus laporan yang diterima.

3. Majelis Pemeriksa sebagaimana dimaksud pada ayat (1) dibantu oleh 1 (satu) orang sekretaris.

4. Pembentukan Majelis Pemeriksa dilakukan paling lambat 5 (lima) hari kerja setelah laporan diterima.

5. Majelis Pemeriksa sebagaimana dimaksud pada ayat (1) wajib menolak untuk memeriksa Notaris yang mempunyai hubungan perkawinan atau hubungan darah dalam garis lurus ke atas atau ke bawah tanpa pembatasan derajat, dan garis lurus ke samping sampai dengan derajat ketiga dengan Notaris.

6. Dalam hal Majelis Pemeriksa mempunyai hubungan sebagaimana dimaksud pada ayat (5), Ketua MPN menunjuk penggantinya.

Pengaturan pengawasan dan pemeriksaan seperti itu memperpanjang rantai pengawasan dan pemeriksaan dengan keharusan majelis pengawas untuk membentuk tim pemeriksa dan majelis pemeriksa untuk melakukan pemeriksaan tertentu. Menurut penulis, 
Otentik's: Jurnal Hukum Kenotariatan (Vol 2, No. 2, Juli 2020)

p-ISSN 2655-5131 e-ISSN 2685-3612

lebih baik yang melakukan pengawasan dan pemeriksan notaris yaitu majelis pengawas dengan segala kewenangan yang ada menurut UUJN dan Peraturan Menteri tersebut.

MPN memiliki wewenang untuk menjatuhkan sanksi terhadap notaris. Sanksi ini diatur dalam UUJN, juga disebutkan kembali dan ditambah dalam Peraturan Menteri Hukum Dan Hak Asasi Manusia Republik indonesia Nomor: M.02.PR.08.10 Tahun 2004 tentang Tata Cara Pengangkatan Anggota, Pemberhentian Anggota, Susunan Organisasi, Tata kerja, dan Tata Cara Pemeriksaan Majelis Pengawas Notaris Jo Peraturan Menteri Hukum dan Hak Asasi Manusia Nomor 40 Tahun 2015 tentang Susunan Organisasi Tata Cara Pengangkatan Anggota, Pemberhentian Anggota, dan Tata Kerja Majelis Pengawas. Dengan pengaturan seperti itu ada pengaturan sanksi yang tidak disebutkan dalam UUJN tapi ternyata diatur atau disebutkan juga dalam Peraturan Menteri Hukum Dan Hak Asasi Manusia Republik indonesia Nomor: M.02.PR.08.10 Tahun 2004 tentang Tata Cara Pengangkatan Anggota, Pemberhentian Anggota, Susunan Organisasi, Tata kerja, dan Tata Cara Pemeriksaan Majelis Pengawas Notaris Jo Peraturan Menteri Hukum dan Hak Asasi Manusia Nomor 40 Tahun 2015 tentang Susunan Organisasi Tata Cara Pengangkatan Anggota, Pemberhentian Anggota, dan Tata Kerja Majelis Pengawas.

Pada dasarnya tidak semua Majelis Pengawas mempunyai wewenang untuk menjatuhkan sanksi, meskipun MPD mempunyai wewenang untuk menerima laporan dari masyarakat dan dari notaris lainnya dan menyelenggarakan sidang untuk memeriksa adanya dugaan pelanggaran kode etik notaris atau pelanggaran pelaksanaan Jabatan notaris tapi tidak diberi kewenangan untuk menjatuhkan sanksi apapun, MPD hanya berwenang untuk melaporkan hasil sidang dan pemeriksaannya kepada MPW dengan tembusan kepada pihak yang melaporkan, notaris yang bersangkutan kepada MPP, dan Organisasi Notaris.

MPW hanya dapat menjatuhkan sanksi berupa sanksi berupa teguran lisan atau tertulis, dan sanksi seperti ini bersifat final dan mengusulkan pemberian sanksi terhadap notaris kepada MPP berupa pemberhentian sementara dari jabatan notaris selama 3 (tiga) bulan sampai dengan 6 (enam) bulan atau pemberhentian dengan tidak hormat dari jabatan notaris. Sanksi dari MPW berupa teguran lisan dan teguran tertulis dan bersifat final tidak dapat dikategorikan sebagai sanksi tapi merupakan tahap awal dari aspek prosedur paksaan nyata dalam untuk kemudian dijatuhi sanksi yang lain, seperti pemberhentian sementara dari jabatannya. 
Otentik's: Jurnal Hukum Kenotariatan (Vol 2, No. 2, Juli 2020)

p-ISSN 2655-5131 e-ISSN 2685-3612

Dalam Pasal 77 huruf c UUJN menentukan bahwa MPP berwenang menjatuhkan sanksi pemberhentian sementara. Sanksi seperti ini merupakan masa menunggu dalam jangka waktu tertentu sebelum dijatuhkan sanksi yang lain, seperti sanksi pemberhentian tidak hormat dari Jabatan Notaris atau pemberhentian dengan hormat dari Jabatan Notaris. Sanksi-sanksi yang lainnya, MPP hanya berwenang untuk mengusulkan:

1. Pemberian sanksi berupa pemberhentian dengan tidak hormat dari jabatannya kepada Menteri.

2. Pemberian sanksi berupa pemberhentian tidak hormat dari jabatannya dengan alasan tertentu.

Dengan demikian, sanksi berupa teguran lisan dan teguran tertulis hanya dapat dijatuhkan oleh MPW. Sanksi berupa pemberhentian sementara dari Jabatan Notaris hanya dapat dilakukan oleh MPP, dan sanksi berupa pemberhentian tidak hormat dari Jabatan Notaris dan pemberhentian dengan hormat dari Jabatan Notaris hanya dapat dilakukan oleh Menteri atas usulan dari MPP. Pada dasarnya, pengangkatan dan pemberhentian notaris dari jabatannya sesuai dengan aturan hukum yang mengangkat dan yang memberhentikan harus instansi yang sama, yaitu Menteri.

MPN memiliki peran yang sangat penting, dalam melakukan pengawasan yang dilakukan oleh majelis tidak hanya pelaksanaan tugas jabatan notaris agar sesuai dengan ketentuan UUJN, tapi juga kode etik notaris dan tindak tanduk atau perilaku kehidupan notaris yang dapat mencederai keluhuran martabat jabatan notaris dalam pengawasan majelis pengawas berdasarkan Pasal 67 ayat (5) UUJN. Hal ini menunjukkan sangat luas ruang lingkup pengawasan yang dilakukan oleh MPN.

Dalam melaksanakan peranannya baik yang diberikan ataupun yang telah ditentukan dalam UUJN maupun Peraturan Menteri Hukum dan Peraturan Menteri Hukum Dan Hak Asasi Manusia Republik indonesia Nomor: M.02.PR.08.10 Tahun 2004 tentang Tata Cara Pengangkatan Anggota, Pemberhentian Anggota, Susunan Organisasi, Tata kerja, dan Tata Cara Pemeriksaan Majelis Pengawas Notaris Jo Peraturan Menteri Hukum dan Hak Asasi Manusia Nomor 40 Tahun 2015 tentang Susunan Organisasi Tata Cara Pengangkatan Anggota, Pemberhentian Anggota, dan Tata Kerja Majelis Pengawas, MPN memiliki beban moral dan kewajiban yang harus dilaksanakan untuk menjamin pelaksanaan tugas jabatan notaris agar sesuai dengan ketentuan UUJN, Kode Etik, dan AD/ART notaris. 
Otentik's: Jurnal Hukum Kenotariatan (Vol 2, No. 2, Juli 2020)

p-ISSN 2655-5131 e-ISSN 2685-3612

Menurut penulis dalam pelaksanaan pengawasan yang dilakukan oleh MPN masih banyak kendala-kendala yang dihadapi oleh MPN karena badan ini berbentuk majelis, yang terdiri dari berbagai unsur, sehingga terkadang sulit bagi setiap anggota majelis untuk mensinergikan waktu antara anggota majelis yang satu dengan yang lain karena pekerjaan utama masing-masing anggota majelis.

Sejalan dengan keterangan Deden Firmansyah bahwa kendala yang pertama, MPN itu bentuknya majelis jadi terkadang untuk lengkapnya para anggota majelis itu susah karena kesibukan masing masing, jadi memang untuk anggota majelis yang betul-betul fokus dalam melakukan pengawasan di MPD juga agak sulit karena ini juga bukan pekerjaan pokok, berbeda seperti majelis hakim, majelis hakimkan sudah jelas bahwa itu pekerjaan khususnya untuk menangani perkara, sedangkan majelis pengawas memang hanya badan dan setiap anggota majelis memiliki profesi dan pekerjaan pokok masing-masing, sebagaimana di atur dalam UUJN Peraturan Menteri Hukum Dan Hak Asasi Manusia Republik indonesia Nomor: M.02.PR.08.10 Tahun 2004 tentang Tata Cara Pengangkatan Anggota, Pemberhentian Anggota, Susunan Organisasi, Tata kerja, dan Tata Cara Pemeriksaan Majelis Pengawas Notaris Jo Peraturan Menteri Hukum dan Hak Asasi Manusia Nomor 40 Tahun 2015 tentang Susunan Organisasi Tata Cara Pengangkatan Anggota, Pemberhentian Anggota, dan Tata Kerja Majelis Pengawas.

Kendala lain karena kewenangan MPN saat ini juga terbatas hanya pembinaan, pengawasan, pembinaan administrasi dan pengawasan administrasi yang dilakukan 1 (satu) sekali minimal 1 kali, jadi MPN akan berkeliling untuk memeriksa protokol notaris dan keadaan kantornya, dan untuk saat ini hanya bisa dilakukan 1 (satu) kali, dan dalam 1 (satu) hari, MPN hanya memeriksa maksimal 4 (empat) notaris, dan karena para anggota memiliki pekerjaan pokok masing-masing, jadi MPN juga harus menjadwalkan kapan pemeriksaaan ini bisa menyesuaikan dengan jadwal yang tidak begitu padat dengan pekerjaan masingmasing anggota majelis, dan MPN memberikan pemberitahuan 7 (tujuh) hari sebelum melakukan pengawasan apalagi dengan jumlah notaris di Kota Bandung sebanyak 238 (dua ratus tiga puluh delapan) orang sedangkan untuk Provinsi Jawa Barat sebanyak 3896 (tiga ribu delapan ratus Sembilan puluh enam) orang yang terdaftar.

Kendala lain menurut Wira Franciska yaitu, dalam proses persidangan terhadap Notaris wajib dihadiri oleh para anggota majelis yang terdiri dari 3 (tiga) unsur yaitu: 3 (tiga) 
Otentik's: Jurnal Hukum Kenotariatan (Vol 2, No. 2, Juli 2020)

p-ISSN 2655-5131 e-ISSN 2685-3612

Perwakilan Notaris, 3 (tiga) Perwakilan Akademisi, dan 3 (tiga) Perwakilan Pemerintah, apabila tidak terjadi titik permusyawarahan dan mufakat maka dalam memustuskan hasil sidang pemeriksaan akan dilakukan secara voting. Apabila dilakukan secara voting.

Menurut penulis hal ini akan terjadi ketidakadilan terhadap notaris, karena suara voting 3 (tiga) banding 6 (enam). Dimana 3 (tiga) dari suara Notaris, 6 (enam) dari suara Akademisi dan Pemerintah. Berbeda dengan organisasi Ikatan Dokter Indonesia dimana justru hampir keseluruhan anggota Majelis adalah para dokter-dokter itu sendiri dalam Peraturan Konsil Kedokteran Indonesia Nomor 3 Tahun 2011 Tentang Organisasi Dan Tata Kerja Majelis Kehormatan Disiplin Kedokteran Indonesia Dan Majelis Kehormatan Disiplin Kedokteran Di Tingkat Provinsi, yaitu: Keanggotaan Unsur dan Jumlah Pasal 15

Selanjutnya kendala Menurut Fitra Deni , saat ini dalam proses persidangan notaris karena tidak ada pengaturan tentang petunjuk pelaksanaan dan petunjuk teknis persidangan notaris maka terkadang pada fakta yang ada dilapangan pengacara turut hadir dalam sidang bahkan menggantikan notaris yang menjadi terlapor, seolah-olah pengacara menyamakan persidangan MPN dengan persidangan dalam sistem peradilan yang ada, menurut Fitra Deni, apabila ini menyangkut persidangan kode etik maka pengacara tidak tepat sebagai penerima kuasa hadir di persidangan untuk mewakili notaris, jika memberikan jawaban atau kesimpulan itu dibolehkan saja selama itu di luar persidangan karena ini menyangkut kode etik notaris, akan tetapi faktanya banyak sekali notaris tidak hadir namun diwakilkan oleh pengacara sebagai penerima kuasa yang menghadiri persidangan, karena akan sulit menyidangkan kode etik karena yang hadir adalah pengacara sebagai penerima kuasa bukan notaris sebagai pihak terlapor, ini merupakan ketidaktahuan dari MPN, maka dalam hal ini ketika MPN yang diangkat oleh menteri maka harus memenuhi kriteria yang sesuai, dengan pemahaman dalam proses beracara dalam persidangan dan memiliki personality yang baik, selain itu dalam proses persidangan MPN perlu difasilitasi ruang sidang khusus dalam proses beracara persidangan yang di lakukan oleh MPN karena ini menyangkut harkat dan martabat notaris ditambah anggota majelis tidak menggunakan toga sehingga wibawa seorang MPN tidak terlihat professional serta hasil putusan dalam sidang majelis para pihak tidak mendapat tembusan sehingga menurut penulis dalam hal ini juga masih ada kelemahankelemahan baik didalam UUJN dan Peraturan Menteri Hukum Dan Hak Asasi Manusia Republik indonesia Nomor: M.02.PR.08.10 Tahun 2004 tentang Tata Cara Pengangkatan 
Otentik's: Jurnal Hukum Kenotariatan (Vol 2, No. 2, Juli 2020)

p-ISSN 2655-5131 e-ISSN 2685-3612

Anggota, Pemberhentian Anggota, Susunan Organisasi, Tata kerja, dan Tata Cara Pemeriksaan Majelis Pengawas Notaris Jo Peraturan Menteri Hukum dan Hak Asasi Manusia Nomor 40 Tahun 2015 tentang Susunan Organisasi Tata Cara Pengangkatan Anggota, Pemberhentian Anggota, dan Tata Kerja Majelis Pengawas itu sendiri.

\section{KESIMPULAN}

Berdasarkan hasil analisis yang dilakukan peneliti diperoleh kesimpulan sebagai berikut Peran MPN Jawa Barat terhadap laporan masyarakat belum efektif karena pada sidang pemeriksaan tingkat pertama di MPD hanya sebatas menyelenggarakan sidang untuk memeriksa adanya dugaan pelanggaran kode etik notaris atau pelanggaran pelaksanaan jabatan notaris pemeriksaan terhadap dugaan dari laporan masyarakat karena pada dasarnya MPD lebih mengatahui situasi dan kondisi permasalahan yang ada di daerahnya dan ketika hasil pemeriksaan dari MPD direkomendasikan ke MPW baik pelapor maupun terlapor sering tidak hadir dalam proses persidangan yang dilaksanakan MPW.

Kendala-Kendala Majelis Pengawas Notaris Jawa Barat Dalam Melakukan Pengawasan Masih banyak kekurangan-kekurangan dalam pelaksanaan maupun peraturan terkait notaris, sehingga menimbulkan kendala-kendala dalam proses pelaksanaannya, kendala-kendala yang dihadapi MPN yaitu jumlah MPN tidak seimbang dengan jumlah notaris yang diawasi dimana jumlah MPN lebih sedikit dibandingkan dengan jumlah notaris di Provinsi Jawa Barat, ditambah dengan wilayah luas dan menyesuaikan waktu antara setiap anggota majelis untuk melakukan pembinaan dan pengawasan agak sulit serta dalam proses persidangan Majelis belum ada petunjuk teknis dan petunjuk pelaksanaan dalam beracara.

Saran yang dapat peneliti ajukan berdasarkan hasil penelitian ini adalah sebagai berikutMemberikan kewenangan kepada MPD untuk memutuskan dan memberi sanksi terhadap notaris yang terbukti melakukan pelanggaran pelaksanaan jabatan notaris, Dalam pembentukan peraturan tentang pembinaan dan pengawasan selanjutnya, membuat petunjuk pelaksanaan dan petunjuk teknis dalam proses sidang Majelis Pengawas Notaris.

\section{DAFTAR PUSTAKA}

\section{Buku}

Habib Adjie, Memahami Majelis Pengawas dan Majelis Kehormatan Notaris, Bandung: Refika Aditama, 2017. 
Otentik's: Jurnal Hukum Kenotariatan (Vol 2, No. 2, Juli 2020)

p-ISSN 2655-5131 e-ISSN 2685-3612

W.J.S. Poerwadarminto, Kamus Umum Bahasa Indonesia, Jakara: PN Balai Pustaka, 1984.

Soerjono Soekanto, Pokok-pokok Sosiologi Hukum, Jakarta: Grafindo Persada, 2003.

Soerjono Soekanto, Sosiologi Suatu Pengantar, Jakarta: Grafindo Persada, 1990.

Hani Handoko, Manajemen Personalia dan Sumber Daya Manusia, Jakarta: Rafika Aditam, 1999.

Sarwoto, Dasar-Dasar Organisasi dan Management, Jakarta: Ghalia Indonesia, 2010.

M. Manullang, Dasar-Dasar Management, Jakarta: Ghalia Indonesia, 1977.

Victor M. Situmorang, Jusuf Juhir, Aspek Hukum Pengawasan Melekat, Jakarta, Rineka Cipta, 1994.

Makmur, Efektivitas Kebijakan Pengawasan, Bandung: Refika Aditama, 2011. 